\title{
Roman Bodański
}

\section{Minister pogrzebu na cmentarzu komunalnym}

Prawo Kanoniczne : kwartalnik prawno-historyczny 18/3-4, 181-193

1975

Artykuł został zdigitalizowany i opracowany do udostępnienia w internecie przez Muzeum Historii Polski w ramach prac podejmowanych na rzecz zapewnienia otwartego, powszechnego i trwałego dostępu do polskiego dorobku naukowego i kulturalnego. Artykuł jest umieszczony w kolekcji cyfrowej bazhum.muzhp.pl, gromadzącej zawartość polskich czasopism humanistycznych i społecznych.

Tekst jest udostępniony do wykorzystania w ramach dozwolonego użytku. 


\section{MINISTER POGRZEBU NA CMENTARZU KOMUNALNYM}

Tresc: Wstęp. - I. Proboszcz miejsca zamieszkania zmarłego. II. Proboszcz miejsca zgonu. - III. Minister z wyboru. - IV. Zakończenie.

\section{Wstęp}

Ministra obrzędów pogrzebowych wyznaczają trzy tytuly prawne: miejsce zamieszkania zmarłego, miejsce zgonu i prawnie wyrażona wola zmarłego.1 Powyższe tytuły mogą wyznaczać jednego, dwóch lub w skrajnych wypadkach więcej ministrów do jednego pogrzebu, każdego do innej części.2 Prawo pogrzebowe Kodeksu prawa kanonicznego jest dość szczególowe i wystarczająco wyraźnie określa, kto ma prawo i obowiązek pełnić funkcję ministra w poszczególnych wypadkach. ${ }^{3}$ Wyjątek stanowią tylko przepisy dotyczące kompetencji ministra na cmentarzu komunalnym i w pocho-

1 Kan. 1216, $1218 \S 1,1223 \S 1$. Wyrazem domniemanej woli zmarłego, w sprawie miejsca pochowania jest położenie grobowca rodzinnego, kan. $1229 \S 1$.

2 Conte a Coronat a M., Institutiones iuris canonici, vol II, Romae 1951, 113, n. 803; J on e H., Commentarium in Codicem iuris canonici, t. II, Paderborn 1954, 428; V e r meer s ch A. - Creusen J., Epitome iuris canonici, t. II, Mechliniae-Romae 1940, s. 376, n. 536. Por. kan. $1230 \S 3,4$ i 7.

8 Warto tu podkreślic, że nowe przepisy liturgiczne pogrzebu, „Ordo exsequiarum", z dnia 15 sierpnia 1969 roku, ogłoszone przez Kongregację do Spraw Kultu Bożego (wydanie samoistne jako wkładka do przyszłego rytuału, zob. Posoborowe prawodawstwo koscielne, opr. Sz t a f r ow s ki E., t. III, z. 2, Warszawa 1971 , s. 26-47) nie zastąpiły prawa pogrzebowego Kodeksu prawa kanonicznego, lecz tylko dawne przepisy liturgiczne pogrzebu, zawarte $w$ Rytuale rzymskim. W prawie kodeksowym wprowadzają one tylko minimalne zmiany, dotyczące możliwości ograniczenia pogrzebu tylko do domu żałoby, kościoła lub cmentarza. Miejsca te nazwane zostały stacjami. Kodeks zobowiązywał do odprawienia calego pogrzebu, obejmującego wszystkie trzy miejsca. Dla ważnej przyczyny można było ten nakaz pominąć, kan. 1215. Konferencja Episkopatu może nadal utrzymać obowiazek odprawienia pogrzebu we wszystkich trzech stacjach. Zob. Ordo exsequiarum, n. 4 i 9. 
dzie na ten cmentarz (w kondukcie). ${ }^{4} \mathrm{Są} \mathrm{tu} \mathrm{pewne} \mathrm{niedomówienia}$ j niejasności. Przyczyną ich, zdaje się, jest dość wyraźne założenie Kodeksu, że pogrzeby kościelne odbywają się tylko na cmentarzach kościelnych. Pominięty jest więc problem kompetencji ministra na cmentarzu komunalnym.5 Przy takiej koncepcji Kodeksu, kompetencję ministrów na cmentarzu reguluje kan. $1228 \S 1$ i 2 . Zobowiązuje on ministra $z$ obcego terenu do uzyskania zezwolenia u zarządcy cmentarza na pochowanie zwłok na danym cmentarzu. ${ }^{6}$ Zarządca może nie zezwolić.7 W konsekwencji szczegółowe przepisy określające kompetencję ministra na cmentarzu kościelnym stały się zbędne. Decyduje tu zezwolenie zarządcy. $Z$ chwilą rozpowszechnienia się cmentarzy komunalnych, 8 nie posiadających swojego zarządcy kościelnego, problem kompetencji ministra stał się bardziej złożony. Niedomówienia i niejasności Kodeksu stały się widoczne w odniesieniu do cmentarzy komunalnych $z$ powodu braku ingerencji zarządcy kościelnego. Wymagają one wyjaśnień. Do tego dochodzą jeszcze lu$\mathrm{ki}$ w prawie partykularnym ${ }^{9} \mathrm{i}$ zdeaktualizowanie niektórych norm Kodeksu, w dziedzinie prawa pogrzebowego.

Okazją do zajęcia się przedstawionym tematem było pismo pewnego administratora parafii dziekańskiej, w mieście powiatowym, posiadającym szpital, skierowane do Kurii Biskupiej. Pismo zawierało w sobie coś, w rodzaju skargi połączonej z pytaniem w kwestii prawnej. Dotyczyło praktyki stosowanej przez administratorów okolicznych parafii, chowania zmarkych na cmentarzu komunalnym miasta. Autor listu pytał się Kurię, czy mogą to czynic bez jego zezwolenia.

Mimo braku bliższych danych, pismo wzbudziło tyle problemów prawnych, że uznałem je za godne poważniejszych dociekań. W trakcie poszukiwań materiału nasunął się wniosek, że miejsca nadające się do interpretacji można i należy wykorzystać do rozszerzenia

$4 \mathrm{~W}$ dalszym ciągu artykułu ujmuję te dwa problemy w jednym pojęciu: „,kompetencja ministra na cmentarzu”.

5 We rn z F., Jus canonicum, t. IV, vol. I, Romae 1934, s. 707, n. 592.

- Kan 1228 \& 1 i 2.

7 Według niektórych kanonistów zarządca cmentarza nie ma obowiązku przyjąć zwłok zmarłego z obcej parafii, jeżeli obrzędy pogrzebowe odbyły sie $w$ innej parafii. J on e H., Commentarium, s. 424; V e r n z F., Jus canonicum, 709, n. 593. Inaczej twierdzi C a p ello: proboszcz nie może odmówić przyjęcia zwłok, ale może domagać się opłaty. C a p p e Ilo F., Summa iuris canonici, vol. II, Romae 1951, s. 460 , n. 487 , ust. 1.

8 Cmentarze komunalne zostaly wprowadzone w 18 i 19 wieku, szczególnie $w$ dużych miastach, na miejsce zniesionych cmentarzy partykularnych. W e r n z F., Jus canonicum, s. 707, n. 592. Rozpowszechnily sie już po ogłoszeniu Kodeksu. W Polsce stały się zjawiskiem powszechnym po wyjściu ustawy $z$ dnia 31 stycznia 1959 r. o cmentarzach i chowaniu zmarłych - Dz. U. Nr 11, poz. 62 .

$\mathrm{Na}$ przyklad brak jest $\mathrm{w}$ wielu diecezjach dekretów ordynariusza przewidzianych w kan. $1218 \S 2$. 
praw proboszcza miejsca zamieszkania osoby zmarłej, zwanego krótko proboszczem własnym.10 Przemawia za tym wiele racji, Kodeks prawa kanonicznego przyznaje proboszczowi własnemu uprzywilejowanie prawne, które polega na tym, że w wątpliwości, w sprawie właściwości parafii do pochowania zmarłego przeważa zawsze prawo własnej parafii,11 a tym samym i prawo własnego proboszcza. ${ }^{12}$ Komentatorzy podkreślają, że jest bardzo wskazane, żeby zmarłego chował ten, kto miał prawo udzielać mu sakramentów św. i głosić słowo Boże.13 Przemawiają za tym również inne racje duszpasterskie. Proboszcz własny lepiej zna zmarłego i jego rodzinę i dlatego owocniej może wykorzystać liturgię pogrzebową, a zwlaszcza homilię mszalną, czy mowę pogrzebową i czytania liturgiczne do duszpasterskiego oddziaływania. Ewentualne uczuciowe zaangażowanie duszpasterza może być dla rodziny wydatną pociechą i podtrzymaniem na duchu, które może się przerodzić na przyszłość w głębsze przywiązanie do duszpasterza i do Kościoła. ${ }^{14}$

Przez prawo pogrzebowe Kodeksu prawa kanonicznego przewija się dość wyraźnie wola prawodawcy, równomiernego rozłożenia pogrzebów na poszczególne parafie, celem uniknięcia zbyt rażącej kumulacji w jednej parafii, kosztem drugich. Zbytnia kumulacja grozi zawsze zrutynizowaniem $w$ odprawianiu liturgii pogrzebowej ku zgorszeniu wiernych. Grozi to zwłaszcza parafiom wielkomiejskim, mającym na swym terenie cmentarz komunalny, wspólny dla wielu parafii lub też szpital dla okolicznej ludności. Duszpasterze takiej parafii musza zbyt wiele czasu poświęcać pogrzebom, kosztem innych obowiązków, zwłaszcza w dziedzinie katechezy. Wreszcie zasada sprawiedliwości w wynagradzaniu duchowieństwa, postulowana przez Sobór Watykański II i przez dekrety wykonawcze do uchwal tego Soboru,15 wymaga przeciwdziałania tendencji większych parafii do mnożenia dochodów ,iura stolae”, za pogrzeby obcych parafian. Dzieje się to przecież kosztem duchowieństwa uboższych parafii wiejskich. Zdaje się, że proponowana zasada interpretacji odpowiada myśli prawodawcy i realizuje jego intencję, mimo pewnych niewielkich odchylen od literalnego sensu przepisów prawa pogrzebowego. Zasada ta zmierza również do złagodzenia zbytniej

10 Parochus proprius ratione domicilii vel quasi-domicilii.

11 Kan. 1217 w zwiazku z kan. 1216 \& 1.

12 Cappello F., Summa iuris, s. 463, n. 490; Conte a Cor on at a M., Institutiones,s. 113, n. 804; V e r z F., Jus canonicum, s. 715, n. $600, \mathrm{I}$.

${ }_{13}$ Vermeers ch A. - Creusen J., Epitome iuris canonici, s. 368, n. 528; Vernz F. Jus canonicum, s. 715 , n. 600.

14 Por. Ordo exsequiarum, uwagi wstępne i nn. 12, 16, 17, 18, 23, 24, p. $1-5,25$, p. 3 .

15 Dekret o posłudze i życiu kapłańskim Presbyterorum ordinis n. 17 i 20; Motu proprio Pawła VI Ecclesiae Sanctae zi 6 sierpnia 1966, n. 8 AAS 58 (1966) s. $757-787$. 
drobiazgowości prawa pogrzebowego przez osłabienie wyjątków, a pradkreślenie i rozszerzenie ogólnej normy o kompetencji własnej parafii i własnego proboszcza. Wiele przepisów prawa pogrzebowego nie znajduje wcale zastosowania $\mathrm{w}$ praktyce, $\mathrm{z}$ powodu zbytniej drobiazgowości. $\mathrm{Z}$ tego powodu jego reforma jest konieczna. Zanim ona nastąpi trzeba robić to co możliwe, żeby prawo pogrzebowe trochę pojaśnić i bardziej sprecyzować.

Przeciw rozszerzaniu kompetencji własnego proboszcza przemawia wprawdzie zasada ekskluzywności władzy proboszczowskiej na własnym terenie, wykluczająca prawo ingerencji innych proboszczów ${ }^{16}$. Nie jest ona jednak absolutna i zna wiele wyjątków. Na przykład prawo spowiadania własnych wiernych na obcym terenie, lub prawo dyspensowania od postu oraz od obowiązku święcenia dnia świętego 17. Także samo prawo pogrzebowe ogranicza ekskluzywność terytorialną miejscowego proboszcza, na rzecz proboszcza własnego ${ }^{18}$. Tam gdzie prawo pogrzebowe rezerwuje kompetencje proboszczowi miejscowemu, czyni to dla uniknięcia zbytnich kosztów, obciążających organizatorów pogrzebu ${ }^{19}$. Tam, gdzie niebezpieczeństwo wielkich kosztów pogrzebowych nie istnieje, ekskluzywność kompetencji miejscowego proboszcza przestaje być celowa. W świetle prawa kanonicznego $\mathrm{i}$ interpretacji prawnej, kompetencje poszczególnych ministrów, $\mathrm{w}$ odniesieniu do cmentarza komunalnego przedstawiają się następująco.

\section{Proboszcz miejsca zamieszkania zmarłego}

Proboszcz własny na terenie swojej parafii może zawsze chować zmarłego. Nie uchodzi żadnej wątpliwości, że te same uprawnienia przysługują mu na cmentarzu komunalnym, wspólnym dla wielu parafii $\mathrm{i}$ właściwym dla jego terenu ${ }^{20}$. Miejsce położenia cmentarza nie odgrywa tu roli, może leżeć cmentarz na terenie jego parafii, a może leżeć i na terenie obcym. Wszystkim proboszczom właściwym ze względu na miejscowość, dla której został przeznaczony cmentarz, przysługuja jednakowe prawa chowania własnych parafian, niezależnie od miejsca położenia cmentarza 21. W tym kierunku idzie interpretacja prawa, przyjęta przez praktykę.

16 Kan. 8 \& 2.

17 Kan. 881 § 2 i kan. $1245 \S 1$.

$18 \mathrm{Na}$ przykład przez prawo prowadzenia konduktu pogrzebowego przez abcy teren (kan. $1232 \S 1$ ), prawo sprowadzenia zwłok $z$ obcej parafii (kan. $1218 \S 13$, kan. $1230 \S 2$ ).

19 Kan. $1218 \S 1-3$, kan $1232 \S 2$.

20 W e r n z F., Jus canonicum, s. 707-709.

21 Por. kan. $1231 \S 1$; Conte a Coron at a M., Institutiones, s. 120 n. 807; W e r n z F., Jus canonicum, s. 707-709. 
Proboszcz może prowadzić kondukt na cmentarz wlasnej parafii przez teren obcy ${ }^{22}$. Tę samą regułę przyjęła praktyka, gdy parafia nie ma swego cmentarza, a zwloki chowa się na cmentarzu komunalnym. Proboszcz na tych samych prawach może prowadzić kondukt przez obce parafie na cmentarz komunalny, właściwy dla jego parafii, dowolnie oddalony. Jest to zupełnie oczywiste. Żaden $z$ proboszczów prawdopodobnie nie wątpi $w$ te uprawnienia. A jednak, w świetle litery prawa jest tu luka prawna, dlatego że Kodeks prawa kanonicznego przyjmuje za zasade, chowanie na cmentarzu należącym do kościoła obrzędów pogrzebowych ${ }^{23}$.

Zwłoki parafianina zmarłego $w$ obcej parafii proboszcz może prowadzić w kondukcie pogrzebowym do wiasnej parafii, celem odprawienia egzekwii i pochowania na cmentarzu własnej parafii. Ale może to uczynić tylko wtedy, gdy przeprowadzenie zwłok pieszo nie jest zbyt trudne, biorąc pod uwagę odległość. Biskup ma określić dla swojej diecezji odległość i inne okoliczności uprawniające proboszcza do przeprowadzenia zwłok, uwzględniając miejscowe warunki 24. Komentatorzy podkreślają, że ordynariusz nie może brać pod uwagę możliwości transportu zwłok koleją, bo to zawsze jest zbyt trudne, ze względu na wydatki obciążające organizatorów 25. Należy zauważyć, że prawo przedkodeksowe było tu bardziej liberalne dla własnego proboszcza. Mógł on prowadzić zwłoki z obcej parafii tak daleko, jak daleko było to bezpieczne. Interpretacja tego przepisu była taka, że kondukt na odległość wymagającą jednego dnia drogi uchodził jeszcze za bezpieczny ${ }^{26}$. Widzę celowiość rozszerzenia uprawnień własnego proboszcza do prowadzenia konduktu $z$ obcej parafii na dalszą odległość. Może to uczynić prawo diecezjalne w oparciu o wspomniany przepis prawa pogrzebowego zawarty w kan. 1218 § 2 . Należy tylko odstąpić od kryterium tego kanonu $w$ sprawie oceny trudności prowadzenia zwlok $w$ kondukcie pieszym. To kryterium jest wyraźnie przestarzałe z powodu rozpowszechnienia się komunikacji samochodowej, wykorzystywanej i do pogrzebôw. W pierwszych kilkunastu latach XX-stego wieku, kiedy Kodeks prawa kanonicznego byl w opracowaniu, kondukt pieszy był zjawiskiem powszechnym, a środki transportu trudno dostępne i kosztowne. Współcześnie jest odwrotnie. Kondukt z samochodem jest

22 Kan. 1232 \& 1.

28 Kan. $1231 \S 1$.

24 Kan. $1218 \S 1$ i 2 , kan. 1230 2. W diecezjach belgijskich, na przykład dopuszczalne było prowadzenie zwlok $\mathrm{z}$ obcej parafii, gdy odleglośc wynosiła 5-8 km. Vermeers ch A. - Creusen J., Epitome iuris, s. 369 , n. 529.

${ }^{25} \mathrm{C}$ onte a Coronat a M., Institutiones, s. 100 , n. 799; Jone $\mathrm{H}$., Commentarium, s. 421; Vermeersch A. - Creusen J., Epitome iuris, s. 369 , n. $529,1$.

${ }^{20} \mathrm{C}$ on te a Cor on a ta M., Institutiones, s. 100, n. 799; Vermeers ch A. - C r e u s en J.,Epitome iuris, s. 369, n. 529. 
zjawiskiem rozpowszechniającym się $\mathrm{i}$ wypierającym zwyczaj prowadzenia zwłok pieszo. Transport samochodowy wydatnie powiększył odległość, przez którą można prowadzić zwłoki bez większych trudności. O ile przy pieszym kondukcie odgrywa rolę każdy kilometr, to przy samochodowym może nie robić różnicy 5 , czy nawet $10 \mathrm{~km}$. Dlatego biskupi winni przedłużyć granicę odległości, licząc się $\mathrm{z}$ faktem, że prawie zawsze wchodzi $\mathrm{w}$ rachubę transport samochodowy ${ }^{27}$. Prawo państwowe już uwzględniło tę sytuację. Zostawia ono zupełną swobodę w przewożeniu zwłok na odległość $60 \mathrm{~km}$, podczas gdy na dalsze odległości potrzebne jest zezwolenie. Przewóz koleją, samolotem i statkiem zawsze wymaga zezwolenia 28 . Swiadczy to, że ustawodawstwo państwowe uważa przewóz zwłok samochodem, na odległość mniejszą niż $60 \mathrm{~km}$, za zjawisko normalne i powszechne, a przewóz innymi środkami transportu, za zjawisko wymagające kontroli i ostrożności. Wydaje się, że byłoby to odpowiednie kryterium współczesne i dla prawa kanonicznego, tak - aby proboszcz własny miał prawo prowadzić zwłoki do swojej parafii na terenie calego powiatu, czy dekanatu, kiedykolwiek zajdzie potrzeba. Zresztą Kodeks prawa kanonicznego przyznaje prawo prowadzenia własnemu proboszczowi, na dowolną odległość, jeżeli organizatorzy pogrzebu podejmą się ponieść koszty związane $z$ takim konduktem 29.

Drogą interpretacji logicznej należy również wprowadzić prawo prowadzenia konduktu przez własnego proboszcza w odwrotnym kierunku - z własnej parafii na obcy teren - ilekroć zajdzie uzasadniona potrzeba chowania zwłok na obcym terenie. Kodeks tego zagadnienia nie porusza, dlatego że bierze pod uwage tylko cmentarze kościelne, a w takim wypadku w grę wchodzi konieczność posiadania zezwolenia na pochowanie na obcym cmentarzu. Jeżeli proboszcz własny uzyska takie zezwolenie to $i$ razem $z$ nim uzyska prawo prowadzenia konduktu na obcy cmentarz. Gdy w grę wchodzi cmentarz komunalny zezwolenie nie jest konieczne i w takim wypadku pożytecznym będzie, prawem analogii, przyznać własnemu proboszczowi, prawo prowadzenia konduktu na cmentarz komunal-

$27 \mathrm{~W}$ wielkich miastach, w niektórych wypadkach kondukt pogrzebowy (nazywany obecnie procesją) jest nawet nie wskazany. Ordo exsequiarum.

${ }_{28}$ art.14, ust. 1 i 2 ustawy $z$ dnia 31 stycznia 1959 r. o cmentarzach $i$ chowaniu zmarłych - Dz. U. z 1972 r. nr 47, poz. 298.

${ }_{29}$ Kan. 1218 § 3 . Kanoniści nie są pewni, czy do granicy własnej parafii nie przysługuje proboszczowi miejsca zgonu prowadzenie zwlok. Nie wykluczają prawa własnego proboszcza do prowadzenia zwłok w całym kondukcie. J on e H., Commentarium, s. 427; V e r m e e r s c h A. - C r e us e n J., Epitome iuris, s. 377, n. 537. Zwyczaj stuletni lub niepamiętny może inaczej postanawiać niż kan. 1230 § 2 . Ca p pello F., Summa iuris, s. 464 , n. 490 , ust. 2 . Zatem, gdy przeniesienie zwłok jest uciążliwe i organizatorzy nie podejmują się tego na własny koszt, prawo zwyczajowe może upoważniać własnego proboszcza do pochowania zmarłego na cmentarzu parafii miejsca zgonu. 
ny przez obcą parafię. Skoro wolno własnemu proboszczowi prowadzić zwłoki $z$ obcej parafii, to wolno i odwrotnie - również na odległość ustaloną przez ordynariusza. Nawiązując do tego, co zostało powiedziane, granice uprawnień powinny się tu również rozciągać ma teren całego powiatu lub dekanatu, tak żeby proboszcz własny mógł odprowadzić zwłoki na cmentarz komunalny najbliższego miasta i tam je pochować. O zamierzonym pogrzebie należy zawiadomić miejscowego proboszcza, jeżeli w danej miejscowości jest tylko jedna parafia. Jeżeli natomiast jest kilka parafii, należałoby zawiadomić proboszcza miejsca położenia cmentarza ${ }^{30}$. Trzeba zaznaczyć, ze ewentualne prawo wlasnego proboszcza do chowania na cmentarzu komunalnym obcej miejscowości, nie można łączyć, przynajmniej w obecnym prawodawstwie, z prawem odprawienia egzekwii w miej-

30 Kan $1230 \S 2$. W tym drugim wypadku, gdy jest kilka parafii, obowiązek zawiadomienia nie jest tak pewny, bo nie spełni zamierzonego celu. Właściwy proboszcz i tak nie będzie poinformowany o wszystkich pogrzebach dokonanych na danym cmentarzu. Należy także uwzględnić obowiązek spisania aktu zgonu. Instrukcja Episkopatu Polski z dnia 26 kwietnia 1954 roku: „Przepisy obowiązujące w sprawie ustalania parafii, w której mają byé spisywane akta obrzędów kościelnych: chrztu, bierzmowania, małżeństwa, pogrzebu", postanawia, że obowiązek spisania aktu zgonu ciąży na proboszczu miejsca pogrzebu. Zob. B ączkowicz F., Prawo kanoniczne, t. II, Opole 1958, s. 605. Zgodnie z ta instrukcją, własny proboszcz jest zobowiązany przekazać miejscowemu proboszczowi informacje, konieczne do spisania aktu zgonu. Obowiązuje to przynajmniej w tych wypadkach, w których sam nie dokonal żadnych czynności pogrzebowych na terenie własnej parafii. Stosując bowiem szeroką interpretację, można powiedzieć, że jakakolwiek czynność ministra, nawet samo nabożeństwo $\mathrm{w}$ kościele swojej parafii, upoważnia do spisania aktu zgonu w księgach swojej parafii. Tym samym, w takim wypadku nie istnieje obowiązek starania się o spisanie aktu zgonu w parafii miejsca pochowania. Parafią pogrzebu jest bowiem nie tylko ta, na terenie której pochowano zwłoki, lecz każda inna, na terenie której dokonano jakichś czynności pogrzebowych. Nieco inaczej wygląda obowiązek spisania aktu zgonu $w$ świetle instrukcji Episkopatu Polski z dnia 7 września 1947 roku: „Przepisy wydane przez Księży Biskupów Polskı o prowadzeniu ksiąg parafialnych: ochrzczonych, bierzmowanych, malżeństw i zmarłych oraz księgi stanu dusz". (Zob. B a c z k owicz F., Prawo kanoniczne, s. 603, n. 21.) Zobowiązuje ona do spisania aktu zgonu proboszcza miejsca zgonu. Moc obowiązująca tego przepisu jest jednak problematyczna, ponieważ instrukcja ta jest wcześniejszej daty, niż instrukcja wymieniona uprzednio $i$ z treści instrukcji późniejszej wynika, że ma ona na celu zmianę instrukcji wydanej uprzednio. Zresztą nie zawsze proboszcz miejsca zgonu jest w stanie zapisać wszystkie zgony zaszle w parafii. Najłatwiejszym do zrealizowania jest przepis kan. 1238, zobowiązujący do spisania aktu zgonu ministra pogrzebu. Zgodnie z tym przepisem, proboszcz wlasny może spisać akt zgonu we wlasnej parafii, również wówczas, gdy pochowa zmarłego na cmentarzu obcej parafii. Odnośnie obowiązku powiadomienia miejsscowego proboszcza o chowaniu zmarlego na terenie parafii, trzeba stwierdzić, że $w$ odniesieniu do cmentarza komunalnego, ten obowiązek nie jest zawsze pewny i powinien byćc dokładniej sprecyzowany, przynajmniej przez prawo partykularne. 
scowym kościele. Nie pozwala na to mocno podkreślane, ekskluzywne prawo miejscowego proboszcza do odprawiania nabożenstw w miejscowym kościele. ${ }^{31}$ Nowe przepisy liturgiczne zezwalają zresztą na oddzielenie od samego pogrzebu nabożeństwa żałobnego w kościele, łącznie ze Mszą św. i na odprawienie go w późniejszym czasie ${ }^{32}$. Dawniejsze przepisy liturgiczne też na to zezwalały, ale w drodze wyjątku ${ }^{33}$. Proboszcz własny może więc przenieść nabożeństwo żałobne $w$ kościele na inny termin i odprawić je we własnej parafii. Będzie to miało tę zaletę, że da okazję udziału w nabożeństwie tym ludziom, którzy nie byli na samym pogrzebie.

\section{Proboszez miejca zgonu}

Przysługuje mu prawo chowania zmarłych, nie posiadających w parafii miejsca zamieszkania, jeżeli odległość do najbliższej własnej parafii zmarłego przekracza granice ustaloną przez ordynariusza i organizatorzy nie podejmują się na własny koszt przeniesienia zwłok do tej parafii ${ }^{34}$. $Z$ kontekstu można zorientować się, że przepis ten dotyczy zgonów $w$ warunkach domowych, a nie $w$ szpitalu. Szpitale, zwłaszcza wielkie, przeznaczone dla terenu obejmującego wiele parafii, stwarzają możliwości nagromadzenia większej ilości zgonów w jednej parafii. Kodeks tego zjawiska nie przewiduje. Trzymając się literalnego sensu Kodeksu ${ }^{35}$, należy prawo chowania ciała osoby zmarłej w szpitalu przyznać proboszczowi miejsca położenia szpitala, jeżeli pogrzeb ma się odbyć na miejscu ${ }^{36}$. Stosując natomiast interpretację logiczną, $\mathrm{z}$ uwzględnieniem kontekstu, pierwszeństwo chowania należy przyznać proboszczowi własnemu ${ }^{37}$. W dalszej kolejności prawo partykularne powinno rozdzielać równomiemie takie pogrzeby między wszystkie miejscowe parafie, $z$ ewentualnym wyróżnieniem parafii zobowiązanej do posługi chorym w danym szpitalu ${ }^{38}$.

W każdym razie, położenie szpitala na terenie tej, czy innej parafii jest kwestią drugorzędną i przypadkową i nie powinno stanowić podstawy do dodatkowych obciążeń i dodatkowych dochodów

\footnotetext{
31 Por. kan. 481, 482, 484, 485.

32 Ordo exsequiarum, n. $6-8$.

38 Kan. 1215.

341218 \& 1 - 3 .

35 Wymaga tego zasada prawna, że nie należy wprowadzać podziału, gdzie nie wprowadza go prawo. „Übi lex non distinguit, nec nos distinguere debemus".

${ }_{36} \mathrm{Kan} .1230$ \& 2, w związku z kan. 1218 \& 1 oraz kan. 1222. Zob. C o nt e a C or o n a t a M., Institutiones, s. 114, n. 804.

37 Por. kan. 1216, 1217, 1230 § 1 . Prawo partykularne może inaczej postanawiać niż Kodeks, kan. 1222.

${ }^{38} \mathrm{Na}$ podstawie kan. 1222.
} 
jednej tylko parafii. Praktyka rozładowuje takie nagromadzenie pogrzebów przez pozostawienie prawa swobodnego wyboru kościoła organizotorom pogrzebu ${ }^{39}$. Wprawdzie prawo kodeksowe nie daje organizotorom takiego prawa, jeśli nie działają jako pełnomocnicy zmarłego ${ }^{40}$, jednak współczesne warunki wymagają bardziej pobłażliwego traktowania woli wiernych, niż przewiduje to prawo kanoniczne. Słuszniejszym mimo to byłby jednak rozdział pogrzebów, o których mowa, według jakiegoś systemu ustalonego przez prawo partykularne. Między innymi po to, żeby nie stwarzać możliwości wybierania kościołów na pogrzeb, na podstawie małostkowych i nieuzasadnionych racji. W każdym razie $\mathrm{w}$ warunkach Polski niecelowe będzie egzekwowanie prawa proboszcza miejsca zgonu w stosunku do zmarłych w dużych szpitalach, obsługujących teren wielu parafii. Byłoby to zaprzeczeniem myśli prawa pogrzebowego Kodeksu.

\section{Minister $\mathrm{z}$ wyboru}

Każdy wierny ma prawo wybrać cmentarz, na którym mają byé pochowane jego zwłoki oraz kościół, gdzie będą odprawione egzekwie ${ }^{41}$. Prawo przedkodeksowe wiązało te dwa przedmioty w jedno prawo wyboru, tak że przez wybór cmentarza wierny wybierał sobie kościół na egzekwie, należący do tej samej osoby prawnej. Obowiązywała wtedy zasada prawna: „Ubi tumulus, ibi funus” 42.

39 Kodeks nazywa ich spadkobiercami, krewnymi, bliskimi lub osobami zainteresowanymi pogrzebem. Kan. $1218 \S 3$, kan. $1229 \S 3$. Nowe przepisy liturgiczne pogrzebu również mówią o rodzinie, domownikach oraz o osobach, ktore zajmują się organizowaniem pogrzebu. Ordo exsequiarum, nn. $16,18,23,24$ p. 1 . Synod diecezji paryskiej przyznaje rodzinie zmarłego w szpitalu prawo wyboru miejsca pogrzebu między parafią szpitala i parafią własną. „Status Synodaux du Diocése de Paris, promulgués dans le Synode de 1956", statut 244. Paris 1957, s. 78.

40 Kodeks pozwala wybrać miejsce pogrzebu tylko osobie, której wybór dotyczy $\dot{i}$ jej pełnomocnikowi. Kan $1226 \S 1$. Organizatorzy mogą na własny koszt przenieść zwloki do własnej parafii, mimo zbyt dużej odległaści, (kan. 1218 § 3) i mogą wybrać grobowiec, jeden z wielu do których zmarły miał prawo (kan. 1229 \& 3). Mogą też wybrać na miejsce pogrzebu jedną z wielu własnych parafii, natomiast nie mogą sprzeciwic się przeniesieniu zwłok do własnej parafii, jeżeli odległosć temu nie przeszkadza. C o n t e a C o ron a t a M., Institutiones, s. 100, n. 799.

Według kanonistów, prawo zwyczajowe może upoważnic organizatorów do wyboru miejsca pogrzebu i kościola obrzędów pogrzebowych. J o n e H., Commentarium, s. 424; Verm'e'er $\mathrm{s} \mathrm{ch} \mathrm{A.} \mathrm{-} \mathrm{Creusen} \mathrm{J.,} \mathrm{Epitome}$ iuris, s. 373 , n. 532. W takim zwyczaju zawiera się zawiązkowo (implicite) wola zmarlego, bo znając zwyczaj za życia, mógl się mu sprzeciwić. $\mathrm{C}$ on te a Cor on a t a M., Institutiones, s. 105, n. 801. Nowe przepisy liturgiczne zalecają uwzględniać życzenia rodziny. Ordo exsequiarum, n. 23.

41 Kan. $1223 \& 1$.

$42 \mathrm{C}$ on te a C or on a t a M., Institutiones, s. 97 , n. 798, II; W e r n z F., Jus canonicum, s. 707, n. 592; Vermeers $\mathrm{ch}$ twierdzi, że nie ma ta- 
Przez wybór cmentarza, czy kościoła wybiera się na ministra pogrzebu rządce odpowiedniej osoby prawnej do której należy kościół lub cmentarz ${ }^{43}$. Prawo kodeksowe złagodziło rygor zasady „Ubi tumulus, ibi funus". Przyznaje ono wiernemu dwa odrębne prawa wyboru, dotyczące kościoła $i$ cmentarza, tak że może on wybrać cmentarz jednej osoby prawnej, a kościół innej ${ }^{44}$. W wypadku, gdy wierny dokonał wyboru tylko jednego przedmiotu - tylko kościola lub tylko cmentarza, istnieje domniemanie w Kodeksie, że wybór dotyczy również drugiego przedmiotu tej samej osoby prawnej, to znaczy, że z kościolem został również wybrany cmentarz tej samej osoby prawnej i odwrotnie. Domniemanie znoszą okoliczności wskazujące na przeciwną wolę zmarłego 45 . Domniemanie jest dopuszczalne, gdy cmentarz i kościól należą do jednej osoby prawnej. Wątpliwa jest możliwość stosowania takiego domniemania, gdy zamiast cmentarza kościelego istnieje cmentarz komunalny ${ }^{46}$, a zupełnie nieuzasadnione ono będzie, gdy cmentarz komunalny jest przezna-

kiej zasady w źródłach prawnych, ani u starożytnych pisarzy. Jest to tylko reguła praktyczna, przyjęta $w$ niektórych regionach, przede wszystkim w Italii. Odpowiedzi Kongregacji potwierdzają istnienie takiego domniemania, ale tylko we Włoszech. Natomiast kanoniści niesłusznie uogólnili to domniemanie na cały Kościół. W rzeczywistości, w wielu regionach, prawo partykularne sprzeciwiało się takiemu domniemaniu. Według autora zasada powinna brzmiec odwrotnie to jest: „Ubi funus ibi tumulus". V e r m e e r c h A. - Cre us en J., Epitome iuris, s. 367-368, n. 527. Autor może mieć rację, ale reguła przez niego podważana jest już tak powszechnie przyjęta w literaturze, że tym samym nabyła pewnej mocy prawnej. Por. kan. 20.

$43 \mathrm{Z}$ pewnymi wyjątkami. Por. kan. 1230 \& 3 i 4; C a p pell o F., Summa iuris, s. 466 , n. 494 ust. 1 i 2 ; Con te a C or on a t a M., Institutiones, s. 117-118, n. 806; W e r n z F., Jus canonicum, s. 717, n. 600.

${ }_{44} \mathrm{C}$ a p pe 110 F., Summa iuris, s. 456, n. 482; J on e H., Commentarium, s. 424; W e r n z F., Jus canonicum, s. 707, n. 591-592; s. 709, n. 593. Wybór kościola, czy cmentarza wiąże tylko wtedy, gdy przeniesienie zwłok nie jest zbyt trudne, lub gdy organizatorzy pogrzebu biora na siebie koszty przeniesienia. Ca p pello F., Summa iuris, s. 462, n. 489, ust. 3, p. 2 .

45 Kan. $1231 \S 1$ i 2 . C a p pe 11 o F., Summa iuris, s. 466, n. 494, ust. 1 i 2; C on te a C or on a t a M., Institutiones, s. 119, n. 807; W e r n z F., Jus canonicum, s. 709, n. 595; Vermeer s h, zgodnie z tezą podaną wyżej twierdzi, że wybór cmentarza nie koniecznie musi zawierać w sobie wybór kościoła. Vermeers ch A. - Creusen J., Epitome iuris, s. 372, n. 532; C on te, wbrew twierdzeniom wyżej cytowanym, też to samo utrzymuje, twierdząc, że $w$ obcej parafii kościól może być wybrany tylko przez wyraźna deklaracje. C on te a Cor on a t a M., Institutiones, s. 98, n. 798, II, s. 107.

${ }^{46} \mathrm{C}$ a p pello F., Summa iuris, s. 456, n. 482, ust. 4, s. 464, n. 490, ust. 3, s. 466, n. 494, ust. 1, s. 467, n. 495; C on te a C or on a t a M., Institutiones, s. 97 , n. 798 , II s. 107 , s. 119 , n. 806; Inaczej J o n e - prawo chowania służy parafii najważniejszej. J on e $\mathbf{H}$., Commentarium, s. 429; Wernz twierdzi, że jeżeli został wybrany kościól w danej miejscowości, to służy mu prawo do całego pogrzebu. Wernz F., Jus canonicum. s. 709, n. 592. 
czony dla wiele osób prawnych. Może więc zaistnieć wypadek, że wierny wybierze sobie cmentarz, nie przesądzając nic o kościele, lub też odwrotnie ${ }^{47}$. Wtedy obowiązuje zasada kan. $1230 \S 7$ o następującej treści: „Jeżeli zwłoki zastają przeniesione do miejsca, gdzie zmarły nie miał ani własnej parafii, ani nie wybrał sobie kościoła na egzekwie, prawo chowania należy do katedry, jeżeli jej nie ma, do parafii na terenie której leży cmentarz, chyba że inaczej postanawia zwyczaj miejscowy lub statuty diecezjalne" 48 . Przepis $§ 7$ odnosi się również do wypadków, gdy zwłoki muszą być pochowane w danej miejscowości, na skutek przypadków losowych. Na przykład zwłoki zmarłego w podróży, jeżeli nikt nie podejmie się przeniesienia ich do miejsca zamieszkania ${ }^{49}$; zwłoki przewiezione do innej miejscowości na zlecenie władz cywilnych, w celu ustalenia przyczyny zgonu ${ }^{50}$. Może również mieć zastosowanie ten paragraf do przypadków, do których nie stosują się inne kanony prawa pogrzebowego w sprawie kompetencji ministra pogrzebowego ${ }^{51}$. Na końcu omawianego przepisu jest klauzula, ze prawo zwyczajowe lub statuty synodalne diecezji moga inaczej postanawiać. Prawo partykularne powinno wykorzystać tę władzę prawodawczą i przyznać w pierwszej kolejności prawo chowania własnemu proboszczowi. Jeżeli obowiązki na to pozwalają i koszty poginzebu nie stoją na przeszkodzie, powinien chować zmarłego własny proboszcz, nawet w miejscu oddalonym i nie związanym ze zmarłym miejscem zamieszkania lub miejscem zgonu. W następnej kolejności, w mieście biskupim, prawo chowania przypada katedirze. Jest to zupełnie zrozumiałe. Katedra, ze względu na specjalną rolę w diecezji, oraz ze względu na to, że przeważnie wyróżnia się architekturą i walorami zabytkowymi, ponosi większe wydatki na konserwację i na wykonywanie funkcji liturgicznych 51. Przy katedrze są również pewne

${ }^{47} \mathrm{C}$ a p pe 11 o F., Summa iuris, s. 464 , n. 490, ust. 3: C o n te a C or o$\mathrm{n}$ a t a M., Institutiones, s. 100, n. 799; s. 118, n. 806; Według Vermeerscha, wybór tylko cmentarza komunalnego daje prawo chowania proboszczowi miejsca położenia cmentarza. Vermeers ch A. - Creusen J., Epitome iuris, s. 379 , n. 538.

48 Kan. 1230 \& 7; Conte a Coronata zaprzecza możliwości stosowania tego przepisu do pogrzebu obcego człowieka na cmentarzu komunalnym. Twierdzi, że regulują go inne przepisy prawa pogrzebowego. Conte a $\mathrm{C}$ or on a t a M., Instiitutiones, s. 118 , n. 806. Nie ma jednak racji. Inne przepisy, była już o tym mowa, dotyczą cmentarza kościelnego, a dla cmentarza komunalnego przepis kan. $1230 \$ 7$ jest najbardziej odpowiedni do określenia kompetencji ministra, chowającego obcego parafianina.

${ }^{49} \mathrm{C}$ a p pe 11 o F., Summa iuris, s. 464, n. 490, ust. 3 ; C on te a C o$\mathrm{r}$ on a t a M., Institutiones, s. 118-119, n. 806.

so Art. 13, ust. 1 ustawy $z$ dnia 31 stycznia 1959 r. o cmenarzach i chowaniu zmarłych - Dz. U. z 1972 r. nr 47, poz. 298. Zwłoki bywaja przewożone do domu przedpogrzebowego, zakładu medycyny sądowej lub szpitala.

${ }^{51}$ Con te a Cor on a t a M., Institutiones, s. 118-119, n. 806. 
rezerwy duchowieństwa, które można wykorzystać przy większej ilości pogrzebów przypadających na jeden dzień, na przykỉad do odprawienia Mszy św. pogrzebowej. Następna natomiast dyspozycja $\S 7$ powinna być interpretowana ze względnością kanoniczną ${ }^{53}$. Dyspozycja ta nie budzi żadnych zastrzeżeń, gdy parafia posiada własny cmentarz. Jest to zresztą przepis pomyślny whaśnie dla cmentarza kościelnego, podobnie jak prawie całe prawo pogrzebowe. Parafia utrzymuje cmentarz, jest jego wyłączym gospodarzem ${ }^{54}$ i jest zupełnie zrozumiałym i naturalnym, że do takiej parafii należy prawo chowania również obcych parafian na własnym terenie. Tak$\dot{z} e$, gdy jest cmentarz komunalny, ale $\mathrm{w}$ danej miejscowości jest tylko jedna parafia, omawiana dyspozycja też jest zrozumiała. Wobec braku alternatywy prawo takiej parafii nie budzi zastrzeżeń. Natomiast, jeżeli cmentarz komunalny jest przeznaczony dla wielu miejscowych parafii, prawo parafii na terenie ktúrej leży cmentarz jest problematyczne. Położenie cmentarza, na terenie tej, czy innej parafii jest kwestią przypadku. Dlatego wszystkie miejscowe parafie powinny mieć równe prawa do chowania obcych zmarłych, jeżeli nie ustala inaczej prawo partykularne. Takie rozwiązanie, w sprawie spornej, dała Stolica Apostolska ${ }^{55}$. Najlepiej byloby, gdyby prawo partykularne ustaliło sposób równomiernego rozdziału pogrzebów obcych parafian między wszystkie miejscowe parafie.

Warto zaznaczyć, że literalnie rozumiane prawo parafii miejsca położenia cmentarza może zbiec się z prawem parafii miejsca położenia szpitala (też literalnie rozumianym) i wtedy nagromadzenie pogrzebów może stać się jeszcze bardziej rażące.

\section{Zakończenie}

Kodeks prawa kanonicznego zawiera zasadę, że kto ma prawo grzebania zmarłego, ten też ma $i$ obowiązek.56 Zasada ta ma na

52 Por. cathedraticum, kan. 1504.

ss Zob. $Z$ u r ow s ki M., Cechy prawodawstwa kanonicznego $w$ swietle posoborowych tendencji, Prawo Kanoniczne 10 (1967) n. 3-4, s. 13-16.

$54 \mathrm{Kan} .1228 \S 1$.

${ }^{55} \mathrm{~W}$ sprawie spornej między dwiema parafiami o prawo pochowania zmarłego, kuria biskupia uznała, że obydwie parafie, jako mające siedaibę $w$ tej samej miejscowości miały równe prawa. Po rekursie parafii niezadowolonej S. Kongregacja Soboru decyzją z dnia 4 lipca 1936 r. utrzymała w mocy decyzję Kurii, motywując, że ponieważ prawo partykularne inaczej nie rozstrzyga, obie parafie mają $w$ tej sprawie jednakowe prawa. AAS 29 (1937) s. 474. Conte a Coronata podaje głos kanonisty przeciwnego tej decyzji. Conte a Coronat a M., Institutiones, s. $118-119$, n. 806.

${ }_{56}$ Kan. $1230 \S 1$. Por. C onte a Cor on at a M., Institutiones, s. 113, n. 803; Vermeersch A. - Creusen J., Epitome iuris, s. 376 , n. 536. 
celu ochrone prawa każdego wiernego do pogrzebu katolickiego.57 Nie można jednak, równomiernie z rozszerzeniem władzy proboszcza własnego do chowania zmarłych poza parafią, rozszerzać również i obowiązku ${ }^{58}$. Obowriązek taki byłby zbyt uciążliwy, a nie jest konieczny, bo prawo wiernego do pogrzebu jest wystarczająco zagwarantowane przez obowiązek grzebania, ciążący na proboszczu miejscowym. Dlatego wystarczy, jeżeli obowiązek ten będzie rozciągał się na teren własnej parafii każdego proboszcza.

\section{Minister funeris in coemeterio communali}

\section{(ARGUMENTUM)}

In re funeraria, Codex iuris canonici, coemeterios tantum Ecclesiae respicit. In coemeterio communali proinde, ius ministri tumulantis non est satis determinatum. Interpretatio in hac re debet esse in favorem parochi proprii, iuxta mentem can 1217. Talem interpretationem etiam rationes pastorales exigunt. Firmis praescriptis Codicis iuris canonici et attentis regulis interpretationis, ius tumulandi in coemeterio communali debet esse un infra.

In coemeterio communali sui loci, parochus proprius ius tumulandi semper habet. Ad hoc coemeterium, idem parochus, potest comitari cadaver, per teritorium alterius parochi, in quamlibet. distantiam. In teritorio districtus vel decanatus, parocho proprio ccmpetere debat cadaver in suam paroeciam deferre, ex aliena paroecia. Norma canonis $1218 \$ 1$ et 2, circa distantiam levandi cadaveris in suam parociam, uti pervetus deroganda est. Parocho proprio etiam competere debet, ut comitetur cadaver in coemeterium alterius loci, in teritorio districtus vel decanatus, ibique tumulet, praemonito parocho lcci. In paroecia, in qua mors accidit (can. $1218 \S 1$ ) ius tumulandi, prima vice, parocho proprio competere debet. Pariter, in casu de quo in can. 1230 \& 7. Postera vice, in his casibus, deficiente paroecia cathedrali, parochis loci in aequo modo, ius funerandi esse debet. Lex particularis statuere debet, quo modo parochi mutentur in eisdem funeribus. Officium funerandi teritorium tantum suae paroeciae attinere debet.

Conte a Coronata słusznie twierdzi, ze od tego obowiązku usprawiedliwiają ważne przyczyny. Wernz twierdzi, że obowiązek ciąży na proboszczu parafii, której cmentarz zostal wybrany na pochowanie. We r nz F., Jus canonicum, s. 417 , n. 600 .

57 Kan. 1215.

58 Conte a Cor on a t a M., Institutiones, s. 120 , n. 807 , J on e H., Commentarium, s. 427.

13 - Prawo Kanoniczne Nr 3-4/75 